\title{
APRESIASI SASTRA SECARA RESEPTIF TERHADAP TEKS PUISI SISWA KELAS X MIPA 9 DI SMA NEGERI 1 SINGARAJA
}

\author{
Ni Luh Putu Yumi Kusuma1, Gede Gunatama², I Made Sutama \\ Jurusan Pendidikan Bahasa dan Sastra Indonesia \\ Fakultas Bahasa dan Seni \\ Universitas Pendidikan Ganesha \\ Singaraja, Indonesia \\ e-mail: yumikusuma@gmail.com,gedegunatama22@gmail.com, \\ made.sutama@undiksha.ac.id
}

\begin{abstract}
ABSTRAK
Penelitian ini dilakukan di SMA Negeri 1 Singaraja. Penelitian ini bertujuan untuk (1) mendeskripsikan struktur teks puisi siswa kelas X MIPA 9 di SMA Negeri 1 Singaraja, (2) mendeskripsikan apresiasi sastra reseptif terhadap teks puisi siswa kelas X MIPA 9 di SMA Negeri 1 Singaraja. Penelitian ini merupakan penelitian deskriptif kualitatif. Subjek dalam penelitian ini adalah siswa kelas X MIPA 9 di SMA Negeri 1 Singaraja, sedangkan objeknya adalah apresiasi sastra reseptif terhadap teks puisi siswa kelas X MIPA 9 di SMA Negeri 1 Singaraja. Penelitian ini menggunakan metode pengumpulan data berupa dokumentasi teks puisi siswa. Instrumen yang digunakan dalam penelitian ini adalah kartu data. Metode analisis data yang dilakukan ada tiga tahap, yaitu reduksi data, penyajian data, dan penyimpulan. Hasil penelitian ini menunjukkan bahwa teks puisi siswa kelas X MIPA 9 di SMA Negeri 1 Singaraja sudah cukup baik dalam memenuhi struktur fisik dan struktur batin puisi. Teks puisi siswa kelas X MIPA 9 di SMA Negeri 1 Singaraja sudah menggunakan struktur fisik berupa diksi (makna kias, simbol, dan rima), pengimajian, dan kata konkret. Teks puisi siswa kelas X MIPA 9 di SMA Negeri 1 Singaraja juga sudah menggunakan struktur batin berupa tema, nada dan suasana, serta amanat. Hasil apresiasi sastra secara reseptif terhadap teks puisi siswa ini adalah secara keseluruhan memiliki kekurangan dan kelebihannya masing-masing.
\end{abstract}

Kata-kata kunci: apresiasi sastra reseptif, teks puisi.

\begin{abstract}
This study took place in SMA Negeri 1 Singaraja. This study aimed to 1) describe text structure of poetry text of $10^{\text {th }}$ grade MIPA 9 Students in SMA Negeri 1 Singaraja, 2) describe receptive literacy appreciation to poetry text of $10^{\text {th }}$ grade MIPA 9 Students in SMA Negeri 1 Singaraja. This study was descriptive qualitative study. The subject was $10^{\text {th }}$ grade MIPA 9 Students of SMA Negeri 1 Singaraja and the object was receptive literacy appreciation to poetry text of $10^{\text {th }}$ grade MIPA 9 Students in SMA Negeri 1 Singaraja. This study used data collection method namely documentation. The instrument which used to obtain the data was data card. There were 3 steps of data analysis such as data reduction, data display and conclusion drawing. The result showed that poetry text of grade MIPA 9 Students in SMA Negeri 1 Singaraja was good enough in terms of physical (diction, symbol, rhyme) and internal (theme, tone, mental situation and moral value) aspect. The result of receptive literacy appreciation to poetry text of these students has strength and weakness
\end{abstract}

Key Words: receptive literacy apreciation, poetry. 


\section{PENDAHULUAN}

Masa remaja dapat menjadi awal masa kreativitas. Pada masa itu, seseorang dapat melakukan sesuatu yang kreatif dan bermanfaat. Inilah yang dapat dikatakan sebagai kreativitas. Sangat banyak jenis kreativitas yang dapat dilakukan, khususnya pada masa remaja. Salah satunya adalah kreativitas dalam menulis. Tidak terkecuali menulis sebuah karya sastra.

Karya sastra merupakan sebuah wadah yang berfungsi untuk menampung ide-ide atau gagasan-gagasan penulis puisi, prosa, dan drama (Yasa, 2012). Sebagai sebuah wadah, karya sastra dapat menampung ide atau gagasan remaja dalam bentuk puisi, prosa, ataupun naskah drama. Sebagai sebuah wadah pula, karya sastra tidak lepas sebagai penampung fenomena sosial di masyarakat yang diangkat menjadi sebuah karya dengan perpaduan unsur imajinatif.

Proses remaja belajar dalam
menghasilkan karya sastra dapa
dilakukan pada setiap jenjang pendidikannya mulai dari SD hingga tingkat pendidikan tertinggi. Di SMA, remaja diajarkan sastra mulai dari penikmatan, penafsiran hingga tahap produksi. Salah satu karya sastra yang paling populer diajarkan di bangku sekolah adalah puisi. Untuk menjadikan siswa lebih produktif dalam pembelajaran sastra, siswa dituntut dapat menghasilkan sebuah puisi. Contoh nyatanya adalah indikator yang terkandung dalam silabus Kurikulum 2013 revisi pada kelas X semester genap tahun ajaran 2016/2017. Dalam silabus pada bab puisi itu terdapat indikator yang menyatakan bahwa siswa harus mampu memproduksi sebuah puisi. Melalui hal itulah siswa selaku remaja mendapat sebuah kesempatan untuk menguji kreativitasnya melalui memproduksi sebuah puisi sebagai karya sastra.

Sebagai pemula dalam menulis puisi, tentunya siswa akan mendapat imajinasi dari sesuatu yang ada di sekitarnya. Tidak dapat dipungkiri pula bahwa, karya sastra terlahir dari fenomena sosial di masyarakat yang diangkat dengan bumbu imajinatif pengarang. Hal itu sejalan dengan teori mimesis. Plato dan Aristoteles (dalam Ratna, 2003) mengungkapkan bahwa teori mimesis memandang karya seni (dalam hal ini sastra) sebagai tiruan masyarakat. Lebih lanjut lagi Ratna (2003) menyatakan bahwa karya sastra, melalui medium bahasa figuratif konotatif memiliki kemampuan yang jauh lebih luas dalam mengungkapkan masalah-masalah yang ada di masyarakat. Tidak hanya pengarang-pengarang yang sudah mahir melakukan tahap mimetik dalam melahirkan karya sastra. Akan tetapi, seorang yang baru belajar sastra seperti siswa pun akan melakukan hal yang sama karena fenomena di masyarakat sangat mudah dijadikan sebagai inspirasi bahkan nantinya juga dapat menghasilkan sebuah amanat.

Sudiara (2014), menyatakan bahwa kelahiran karya sastra akan hambar tanpa kehadiran apresiasi dan kritik sastra. Oleh karena itu, kehadiran puisi dari siswa juga sangat memerlukan adanya sebuah apresiasi dan kritik. Apresiasi dan kritik ini dilakukan guna menghargai puisi siswa dengan cara menikmati dan memberikan masukan kepada puisi siswa. Apresiasi harus mendahului kritik. Dengan adanya apresiasi pada puisi yang telah dibuat oleh siswa, siswa akan dapat mengetahui kekurangan dan kelebihan karyanya. Pengetahuan ini akan berimbas pada siswa. Siswa akan menjadi lebih bijak memperbaiki kekurangannya dan meningkatkan kelebihannya dalam menulis puisi. Dengan pengaruh yang lebih kritis lagi dari siswa, hasil tulisan puisinya akan semakin membaik.

Dalam lingkup sekolah, gurulah yang mempunyai andil besar dalam mengapresiasi karya siswanya. Guru dapat melalukan penikmatan dan pemahaman terlebih dahulu terhadap 
puisi siswa sebelum memberikan penilaian. Tahap penikmatan, tahap pehamaman, dan tahap penilaian merupakan tahap awal apresiasi sastra atau disebut pula sebagai apresiasi sastra secara reseptif.

Dari keadaan yang dipaparkan di atas, dapat timbul pertanyaan "apakah hanya guru yang dapat memberikan apresiasi terhadap karya sastra siswa tersebut; serta bagaimanakah cara mencari perbandingan pendapat subjektif guru dengan pihak lain terhadap karya sastra siswa tersebut". Kesempatan untuk melakukan apresiasi terhadap karya siswa tersebut tentu dapat dilakukan oleh para peneliti, namun harus disertai izin dari pihak sekolah yang berwenang. Dengan adanya penelitian dari para peneliti, akan didapatkan perbandingan pandangan mengenai hasil karya siswa dalam menulis sastra. Berdasarkan fenomena tersebut, dilalukan penelitian mengenai apresiasi sastra reseptif terhadap teks puisi siswa kelas X MIPA 9 di SMA Negeri 1 Singajara.

Apresiasi sastra menurut Efendi (dalam Aminuddin, 2004), adalah kegiatan menggauli karya sastra secara sungguhsungguh sehingga tumbuh pengertian, penghargaan, kepekaan pikiran kritis, dan kepekaan pikiran yang baik terhadap karya sastra. Pengertian apresiasi tersebut menyiratkan pula bahwa kegiatan apresiasi dapat memberikan suatu pemikiran atau tanggapan yang kritis dan baik terhadap sebuah karya. Dengan mengapresiasi karya sastra seperti teks puisi siswa, didapatkan sebuah penilaian yang didasari pemikiran kritis usai melakukan penikmatan dengan cara membacanya. Hal itu sejalan dengan pendapat Zaidan (1991) yang menyatakan bahwa apresiasi puisi itu sebagai penghargaan atas puisi sebagai hasil pengenalan, pemahaman, penafsiran, penghayatan, dan penikmatan karya tersebut yang didukung oleh kepekaan batin terhadap nilai-nilai yang terkandung dalam puisi itu.

Disick (dalam Waluyo, 2005) menyebutkan adanya empat tingkatan apresiasi, yaitu: menggemari, menikmati, mereaksi, dan produktif. Pada tingkat menggemari puisi, seseorang sebatas senang membaca atau menyaksikan pembacaan puisi. Pada tingkat menikmati, seseorang akan tersentuh batinnya saat membaca puisi atau menyaksikan pembacaan puisi. Pada tingkat mereaksi, sikap kritis seseorang terhadap puisi lebih menonjol karena telah mampu menafsirkan dengan kritis dan memberikan penilaian baik atau buruk pada puisi. Tingkat produktif berarti seorang apresiator telah mampu menghasilkan, mengkritik, atau membuat resensi terhadap sebuah puisi secara tertulis. Dari keempat tingakatan tersebut dilakukan penelitian berupa apresiasi hanya pada tingkat ke tiga. Hal itu dikarenakan untuk membuat batasan tujuan penelitian ini sendiri, yaitu untuk mereaksi teks puisi siswa. Oleh karena itu, dapat dikatakan bahwa dilakukan penelitian apresiasi secara reseptif pada teks siswa.

Apresiasi secara reseptif ini adalah kegiatan mengapresiasi dengan teori resepsi pada sebuah karya. Resepsi dapat diartikan sebagai terbuka atau dapat menerima. Jackques Lacan dan Roland Barthes (dalam Aminuddin, 2004:53) menyatakan bahwa sebuah karya sastra setelah hadir di tengah masyarakat pembaca, pembaca sendirilah yang akhirnya memberikan makna. Dalam hal ini, peneliti yang sekaligus berperan sebagai pembaca memiliki peran penting dalam pemberian makna. Dalam penelitian ini dilakukan tindakan meresepsi, memaknai, dan menanggapi teks puisi siswa sebagai karya sastra. Makna menjadi pokok penting dalam merepsi. Hirsch (dalam Sugihastuti, 2002) menyebutkan bahwa makna mengacu pada arti teks dalam kaitannya dengan suatu konteks yang lebih besar. Untuk memaknai teks puisi siswa setepat mungkin, dibutuhkan proses pengaitan arti teks dalam konteks situasi atau keadaan yang berlaku. Jadi, dipilih apresiasi sastra secara reseptif ini karena ingin memberikan suatu penilaian dan tanggapan secara terbuka terhadap teks puisi siswa.

Teks puisi adalah salah satu bentuk karya sastra yang dapat diapresiasi. Pradopo (dalam Gunatama, 2010) menyatakan bahwa puisi adalah 
ekspresi pikiran yang membangkitkan perasaan yang merangsang imajinasi panca indera dalam susunan yang berirama. Semua itu, merupakan hal yang penting dan menarik yang direkam, diekspresikan, dan dinyatakan dengan menarik serta memberikan kesan. Terkait dengan hal itu, puisi ialah interpretasi pengalaman manusia yang diubah dalam wujud yang memberikan kesan. Teks puisi dibuat dengan kepadatan kata-kata estetika, namun memiliki makna yang terpendam. Pemaparan itu tidak terkecuali pula pada teks puisi yang dibuat oleh siswa. Sebagai karya pemula, teks puisi yang dibuat siswa tentu memiliki unsur yang lebih sederhana untuk diteliti dibandingkan teks puisi lain seperti yang diciptakan oleh sastrawan-sastrawan terkenal. Di samping itu, pengapresiasian teks puisi siswa juga dapat memberikan perbandingan pandangan penelitian kepada guru di sekolah.

Dipilih kelas secara acak dalam melakukan penelitian ini karena pengapresiasian dapat dilakukan pada semua jenis teks puisi. Berdasarkan hasil wawancara dengan salah satu guru mata pelajaran bahasa Indonesia di kelas $X$ SMA Negeri 1 Singaraja, kelas X MIPA 9 dinilai aktif dalam pembelajaran. Kelas $X$ MIPA 9 juga memiliki nilai rata-rata yang memenuhi KKM (kriteria ketuntasan minimal) dalam indikator menulis puisi. Pemilihan sekolah juga menjadi pertimbangan peneliti saat akan melakukan penelitian. SMA Negeri 1 Singajara menjadi pilihan karena sekolah ini memiliki kualitas yang sudah tidak diragukan lagi, baik dalam bidang akademik maupun nonakademik. Di Singaraja, sekolah ini merupakan sekolah favorit dan merupakan sekolah negeri terbaik. Hal di atas merupakan alasan digunakannya teks puisi kelas X MIPA 9 di SMA Negeri 1 Singaraja sebagai sasaran apresiasi sastra secara reseptif ini.

Penelitian semacam ini, pernah dilakukan oleh peneliti lain. Penelitian yang pertama dilakukan oleh Solehatul Kamilah pada tahun 2016 dengan judul "Analisis Struktur Fisik dan Struktur Batin Puisi Siswa Kelas VIII A MTs Al-Khairiyah Tegallinggah, Kecamatan Sukasada". Penelitian ini merupakan penelitian deskriptif kualitatif. Penelitian ini membahas struktur fisik dan struktur batin yang ada pada puisi siswa. Penelitian pertama ini memiliki persamaan dengan penelitian yang dilakukan dalam hal mengenali puisi siswa dengan mengetahui struktur fisik dan struktur batin puisi siswa. Perbedaannya adalah penelitian pertama ini hanya menganalisis struktur fisik dan struktur batin puisi. Penelitian yang dilakukan tidak hanya mencari struktur fisik dan struktur batin puisi, tetapi juga melakukan apresiasi secara reseptif terhadap teks puisi siswa kelas X MIPA 9 di SMA Negeri 1 Singaraja. Penelitian yang dilakukan lebih luas daripada penelitian sejenis yang pertama ini.

Penelitian sejenis yang kedua dilakukan oleh Istiningsih yang berjudul "Pelaksanaan Pembelajaran Puisi di sekolah Menengah Pertama (Studi Kasus SMP Negeri 2 Baki, Sukoharjo)" pada tahun 2010. Penelitian ini merupakan penelitian studi kasus di SMP Negeri 2 Baki. Dalam penelitian ini, dibahas mengenai pelaksanaan pembelajaran puisi pada siswa, nilai puisi siswa, hambatan dalam pembelajaran puisi, serta upaya untuk mengatasi hambatan dalam pembelajaran puisi siswa. Persamaan penelitian sejenis kedua dengan penelitian yang dilakukan ini adalah dalam hal mendeskripsikan penilaian pada puisi siswa. Perbedaannya adalah terletak pada hampir seluruh isi penelitian sejenis ini, terutama dalam jenis penelitiannya. Penelitian sejenis ini menggunakan penelitian studi kasus, sedangkan penelitian yang dilakukan adalah penelitian deskriptif kualitatif.

Berdasarkan latar belakang di atas, lahirlah sebuah judul penelitian yang dilakukan. Penelitian itu berjudul "Apresiasi Sastra Reseptif Terhadap Teks Puisi Siswa Kelas X MIPA 9 di SMA Negeri 1 Singaraja". Yang menjadi rumusan masalah dalam penelitian ini adalah 1) bagaimanakah struktur teks puisi siswa kelas X MIPA 9 di SMA Negeri 1 Singaraja dan 2) bagaimakah apresiasi sastra reseptif terhadap teks puisi siswa kelas $X$ MIPA 9 di SMA Negeri 1 Singaraja. 


\section{METODE}

Rancangan penelitian yang digunakan dalam penelitian ini adalah rancangan deskriptif kualitatif karena rancangan ini mampu menggambarkan secara keseluruhan mengenai apresiasi sastra berupa penikmatan, pemaknaan, dan tanggapan yang bersifat reseptif terhadap teks puisi siswa kelas X MIPA 9 di SMA Negeri 1 Singaraja. Yang menjadi subjek dalam penelitian ini adalah siswa kelas $X$ MIPA 9 di SMA Negeri 1 Singaraja. Peneliti memilih siswa kelas $X$ MIPA 9 di SMA Negeri 1 Singaraja sebagai subjek penelitian karena data teks puisi ada pada siswa kelas X MIPA 9 di SMA Negeri 1 Singaraja. Yang menjadi objek penelitian dalam penelitian ini adalah apresiasi sastra reseptif terhadap teks puisi siswa kelas X MIPA 9 di SMA Negeri 1 Singaraja yang dianalisis dengan pendekatan analitik.

Metode pengumpulan data yang digunakan pada penelitian ini adalah metode dokumentasi. Dalam metode ini, data dikumpulkan untuk dipergunakan sebagai bukti atau keterangan di dalam melakukan pengkajian dan penelaahan, seperti pengkajian teks puisi siswa kelas $X$ MIPA 9 di SMA Negeri 1 Singaraja. Untuk selanjutnya, data yang sudah terkumpul atau teridentifikasi dapat dianalisis. Instrumen penelitian yang dipilih berkaitan erat dengan metode pengumpulan data yang digunakan. Sesuai dengan metode yang digunakan, instrumen dalam penelitian ini adalah kartu data. Saat melakukan pengumpulan data, hasilnya akan dicatat dalam kartu data.

Setelah data diperoleh, tugas peneliti selanjutnya adalah menganalisis data. Penelitian ini menggunakan analisis deskriptif kualitatif. Analisis deskriptif kualitatif pada penelitian ini diarahkan pada identifikasi dan klasifikasi untuk mendapatkan deskripsi yang jelas, rinci, dan memadai berkenaan dengan (1) struktur teks puisi siswa kelas X MIPA 9 di SMA Negeri 1 Singaraja, (2) apresiasi sastra reseptif terhadap teks puisi siswa kelas $X$ MIPA 9 di SMA Negeri 1 Singaraja.

Tahapan pertama dalam analisis data ini adalah reduksi data. Tujuannya adalah untuk mengetahui data yang didapat valid atau tidak valid. Data yang ingin peneliti kumpulkan adalah (1) struktur teks puisi siswa kelas X MIPA 9 di SMA Negeri 1 Singaraja, (2) apresiasi sastra reseptif terhadap teks puisi siswa kelas $X$ MIPA 9 di SMA Negeri 1 Singaraja. Tahapan kedua adalah penyajian data. Penyajian data dilakukan dengan menguraikan hal-hal yang telah direduksi ke dalam bentuk uraian sesuai dengan rumusan masalah. Data berupa (1) struktur teks puisi siswa kelas X MIPA 9 di SMA Negeri 1 Singaraja, (2) apresiasi sastra reseptif terhadap teks puisi siswa kelas $X$ MIPA 9 di SMA Negeri 1 Singaraja. Tahapan ketiga adalah penyimpulan. Penyimpulan dilakukan untuk menjawab rumusan masalah sehingga dapat diperoleh informasi mengenai (1) struktur teks puisi siswa kelas $X$ MIPA 9 di SMA Negeri 1 Singaraja, (2) apresiasi sastra reseptif terhadap teks puisi siswa kelas X MIPA 9 di SMA Negeri 1 Singaraja.

\section{HASIL DAN PEMBAHASAN Hasil Penelitian}

Penyajian hasil penelitian adalah gambaran keseluruhan tentang isi penelitian. Dalam penyajian hasil penelitian ini, akan dipaparkan data berupa struktur fisik, struktur batin, dan apresiasi sastra reseptif teks puisi siswa kelas X MIPA 9 SMA Negeri 1 Singaraja. Pada bagian pertama, disajikan hasil analisis puisi siswa yang memenuhi seluruh aspek struktur fisik dan batin puisi. pada bagian kedua, disajikan hasil analisis apresiasi reseptif terhadap teks puisi.

Hasil analisis struktur fisik puisi siswa kelas X MIPA 9 di SMA Negeri 1 Singaraja terdiri atas diksi (makna kias, simbol, dan rima), pengimajian, dan kata konkret. Masing-masing akan diuraikan sebagai berikut ini. Puisi "Taman Kota" karya Deva Satria Wibawa adalah salah satu puisi siswa yang termasuk kategori ideal, yaitu memenuhi seluruh aspek struktur fisik puisi.

Penggunaan diksi pada puisi tersebut sudah tepat. Hal itu terbukti dari pemilihan kata-katanya yang bervariasi. Dilihat dari makna kiasnya, puisi ini 
menggunakan kata yang penuh dengan kepasrahan. Berikut ini merupakan penggalan puisi yang mengandung makna kias.

Semesta bicara tanpa bersuara/Semesta ia kadang buta aksara/Semesta bergulir tak kenal arah/Kaki langit

Makna kias Semesta bicara tanpa bersuara dapat diartikan sebagai sebuah dunia yang mengungkapkan isi hati tidak pernah bersuara, bisa jadi melalui kejadian-kejadian alam. Makna kias Semesta ia kadang buta aksara dapat diartikan sebagai dunia tidak dapat membaca atau tidaklah tahu tentang yang terjadi. Hal itu sesuai kelanjutan pada makna kias selanjutnya. Makna kias Semesta bergulir tak kenal arah dapat berarti bahwa dunia hanya berlalu begitu saja tanpa mengenal waktu dan tidak kenal arah. Kaki langit dapat diwujudkan sebagai sesuatu yang sulit.

Dilihat dari segi penggunaan simbol, penulis mengunakan semesta. Semesta digunakan sebagai simbol kehidupan atau isi bumi. Penggambaran simbol itu sesuai dengan penggalan puisi berikut ini.

Semesta bicara tanpa bersuara/Semesta ia kadang buta aksara/Semesta bergulir tak kenal arah

Penggunaan rima hanya terdapat pada puisi bait pertama, kedua, dan keempat. Bait puisi yang lain tidak memiliki pola yang teratur. Bait pertama dan keempat menggunakan rima kembar pola $a-a-b-b$. Bait kedua menggunakan rima sejajar a-a-a-a. Jadi, dapat dikatakan puisi ini memiliki rima tak sempurna.

Pengimajian puisi juga menambah hidup cerita dalam sebuah puisi. dalam puisi ini terdapat imaji visual dan imaji taktil. Imaji visual dapat dilihat secara langsung bahwa taman kota sedang sepi pengunjung dan hanya ada hamparan rumput yang luas sesuai dengan penggalan puisi berikut ini.

Taman kota sepi senyap/Hanya ada aku dan hamparan rumput

Imaji taktil dapat dirasakan bahwa diam dan membisu dapat mendatangkan perasaan sepi yang indah dan menenangkan, sesuai dengan penggalan puisi berikut ini.
Diam dan membisu/Sepi itu indah, percayalah/Membisu itu anugerah

Kata konkret dalam puisi ini mampu memunculkan imaji yang memperkuat makna puisi. kata konkret dalam puisi ini adalah buta aksara dan hujan dalam mimpi. Buta aksara dapat membangkitkan imaji seolah tidak tahu sesuatu hal. Hujan dalam mimpi juga dapat memunculkan imaji taktil berupa kesejukan yang dialami seseorang, namun hanya sebatas angan atau mimpi. Kepasrahan tetap dipertahankan dalam puisi ini.

Hasil analisis struktur batin puisi siswa kelas X MIPA 9 di SMA Negeri 1 Singaraja yang terdiri atas tema, nada dan suasana, serta amanat. Puisi "Bukakak" karya Desak Made Ardhya sudah memenuhi keempat kriteria yang terdapat dalam struktur batin puisi. Hal itu dapat dilihat dari tema, nada dan perasaan, serta amanat yang terkandung dalam puisi tersebut.

Penggunaan tema ini sudah sesuai dengan isi puisi ini. Sesuai dengan tema yang sudah ditentukan bersama (Buleleng), Bukakak sudah termasuk di dalamnya karena merupakan sebuah tradisi yang hidup di daerah Buleleng sendiri. Sesuai dengan prosesi Bukakak itu sendiri, nada yang digunakan puisi adalah lembut dengan suasana yang sakral. Hal ini juga dapat dilihat dari adanya penggunaan kata dewa padi, istana megah penuh rohani, lambang suci, dan lain sebagainya. Amanat yang dapat ditangkap dari puisi ini adalah tradisi Bukakak sebagai rasa syukur akan anugerah Dewi Sri dalam peran sebagai dewi padi yang telah memberikan rezeki berupa hasil panen yang melimpah.

Berdasatkan analisis di atas, dapat disimpulkan bahwa puisi karya Desak Made Ardhya sudah memenuhi seluruh kriteria struktur batin puisi yang ada. Puisi tersebut merupakan salah satu dari beberapa puisi yang memenuhi keempat kriteria struktur batin puisi.

Untuk menjadikan sebuah karya itu lebih baik, diperlukan sebuah apresiasi terhadapnya agar mendapat penghargaan dan penilaian baik atau buruknya. Apresiasi sastra reseptif ini sebatas menikmati, memahami, serta menanggapi 
keadaan puisi siswa. Berdasarkan hasil analisis, puisi siswa secara keseluruhan memiliki kekurangan dan kelebihannya masing-masing. Dengan ungkapan lain, puisi siswa belum tergolong sempurna. Berikut adalah hasil analisisnya.

Puisi yang mendapat nilai terbaik yaitu "Taman Kota" karya Deva. Puisi yang dituulis mampu mengajak pembaca larut dalam suasana sepi yang disuguhkan. Imajinasi penulis mampu termuat dalam larik-larik puisi yang juga dapat dirasakan pembaca. Ingatan tentang semesta atau dunia yang tidak pernah bisa diduga cukup baik dalam menanamkan pikiran bahwa dunia ini tidak mudah untuk ditaklukan. Namun, puisi tersebut juga mengajarkan arti mencari ketenangan pikiran dalam sepi, menemukan pemikiran untuk mencari jalan terbaik yang akan ditempuh saat masalah menerpa. Apalagi penulis memilih sebuah taman. Dengan adanya pemandangan yang hijau, pikiran akan menjadi tenang. Hanya satu kekurangan dari puisi ini jika disesuaikan dengan kriteria yang ada. Unsur simbol dalam puisi ini tidak disertakan. Padahal jika ada sebuah simbol, puisi ini akan tampak lebih indah.

\section{Pembahasan}

Berdasarkan hasil penelitian, keberhasilan siswa kelas X MIPA 9 di SMA Negeri 1 Singaraja dalam menulis puisi yang dianalisis berdasarkan struktur dan apresiasi reseptifnya dapat dikatakan baik karena sudah mengandung kelima kriteria struktur fisik puisi (diksi yang mengandung makna kias, simbol, dan rima, pengimajian, dan kata konkret) dan keempat struktur batin (tema, nada, perasaan, dan amanat). Hal ini sejalan dengan pendapat Pradopo (1993) menyatakan bahwa puisi adalah ekspresi pikiran yang membangkitkan perasaan, yang merancang imajinasi panca indera dalam susunan yang berirama.

Temuan pertama adalah keberhasilan siswa kelas X MIPA 9 di SMA Negeri 1 Singaraja dalam menulis puisi sudah cukup baik. Puisi siswa tersebut sudah mengandung kelima unsur struktur fisik puisi, meliputi diksi (makna kias, simbol, dan rima), pengimajian, dan kata konkret. Penulis puisi hendaknya menggunakan pilihan kata atau diksi secara tepat, dengan mempertimbangkan makna dan kesesuaian dengan tema yang diangkat. Pemilihan kata yang tepat dapat menggambarkan hal-hal yang diinginkan oleh penulis puisi.

Hal ini sesuai dengan pendapat yang dikemukakan oleh Waluyo (1995) bahwa penyair sangat cermat dalam memilih kata-kata, sebab kata-kata yang ditulis harus dipertimbangkan maknanya, komposisi bunyi dalam rima dan irama, kedudukan kata itu di tengah konteks kata yang lainnya, dan kedudukan kata dalam seluruh puisi itu. Kata-kata yang digunakan ada yang mudah dan ada pula yang sukar diinterpretasikan oleh pembaca. Hal itu membuat kelahiran puisi ada yang mudah dipahami dan ada pula yang memerlukan pemikiran dalam memahaminya.

Penggunaan diksi pada puisi siswa kelas X MIPA 9 SMA Negeri 1 Singaraja dibagi atas tiga bagian, yaitu makna kias, simbol, dan rima. Penggunaan makna kias pada puisi siswa ini sudah cukup baik. Dari 36 puisi siswa, ada 31 puisi yang sudah menggunakan makna kias. Makna kias yang digunakan sangat berviariasi, meliputi tentang alam, kehidupan manusia, bahkan religi. Penggunaan simbol pada puisi siswa dapat dikatakan kurang baik. Hal ini disebabkan oleh tingkat kesulitan penggunaan simbol yang lebih tinggi dari lainnya. Hanya terdapat 14 puisi siswa yang menggunakan simbol dalam puisinya dari total keseluruhan 36 puisi. Penggunaan rima pada puisi dapat dikatakan cukup baik. Terdapat 27 puisi yang menggunakan rima. Namun, hanya ada tiga buah puisi yang menggunakan rima sempurna. Sisanya, puisi siswa menggunakan rima tak beraturan.

Struktur fiksi berikutnya adalah pengimajian. Melalui pengimajian, sesuatu yang digambarkan penulis dalam puisinya seolah-olah dapat dilihat (imaji visual), dapat didengar (imaji auditif), dan dapat dirasakan (imaji taktil). Hal tersebut membuat pembaca larut dan merasakan sesuatu yang digambarkan dalam puisi. hanya ada dua buah puisi yang tidak menggunakan imaji dalam puisi siswa 
yang totalnya berjumlah 36. Dalam struktur fisik puisi, bagian pengimajian inilah yang paling banyak jumlah penggunaannya dalam puisi siswa, sehingga dapat dikatakan sudah cukup baik.

Struktur fisik yang terakhir adalah penggunaan kata konkret. Penggunaan unsure wajib kata konkret pada puisi siswa dapat dikatakan sudah cukup baik. Sebagian besar siswa mengungkapkan puisinya dengan mengkonkretkan katakata dalam puisi. Dalam memahami puisi siswa, cukup memerlukan pemikiran yang baik. Tujuan pemakaian kata konkret ini agar puisi siswa lebih indah dengan katakata yang singkat.

Temuan kedua adalah keberhasilan siswa kelas X MIPA 9 di SMA Negeri 1 Singaraja dalam menulis puisi yang ideal, yakni mengandung keempat struktur batin puisi (tema, nada dan suasana, serta amanat). Puisi dapat diumpamakan sebagai duta perasaan dan pikiran penyair. Lewat puisi yang dituliskan itu, penyair selalu berusaha agar yang terkandung dalam perasaan dan pikirannya dapat terwakili. Dengan demikian nada, dan suasana berperan sebagai pendukung makna dalam suatu puisi. Sebuah tema akan menghasilkan puisi yang berbeda, jika suasana dan perasaan penyair ketika menciptakan puisi tersebut berbeda. Pada akhir pembacaan puisi, akan ditemukan sebuah amanat yang terselip di dalamnya.

Hal itu sesuai dengan pendapat Hutagalung (dalam Gunatama, 2010) yang menyatakan bahwa puisi dapat merangsang kepekaan terhadap keindahan dan kemanusiaan, kehidupan, serta alam sekelilingnya. Berdasarkan pendapat tersebut tersirat puisi dengan keindahannya berfungsi sebagai alat yang berusaha membawa manusia kembali kepada keutuhannya dalam kehidupan. Sebagai salah satu negara yang multibudaya, puisi juga banyak mengungkap keindahannya dan berusaha mengajak untuk tetap melestarikan keberadaannya.

Penggunaan tema pada puisi siswa kelas $X$ MIPA 9 di SMA Negeri 1 Singaraja sama pada setiap setiap puisi. semua puisi siswa sudah ideal karena mengandung tema yang sama. Syarat dalam penulisan puisi ini adalah bertema Buleleng. Dari seluruh puisi siswa, tema Buleleng sudah sesuai dengan masingmasing puisi yang ditulis siswa. Walaupun demikian, ada perbedaan subtema dalam puisi siswa ini. Subtema tersebut terdiri atas sejarah, alam, perpisahan, dan religi.

Untuk mendukung tema, siswa menggunakan nada dan suasana di dalam puisinya. Nada merupakan sikap penyair terhadap pembaca. Dari sikap itu tercipta suasana puisi. Penggunaan nada dan suasana dapat ditemukan pada semua puisi siswa, sehingga dapat dikatakan sudah ideal. Penggunaan nada dan suasana bervariasi padan puisi siswa. Dari nada dan suasana kesedihan hingga nada dan suasana kebahagiaan ada dalam puisi siswa.

Sebagai struktur batin puisi yang terakhir, amanat sudah dapat dikatakan ideal dalam penggunaan puisi siswa. Penggunaan amanat dalam puisi siswa juga tidak monoton antara puisi satu dan lainnya. Ada beragam amanat yang ditemukan pada puisi siswa ini, yaitu tentang kesejarahan, kehidupan, ketuhanan, dan lingkungan atau alam.

Temuan ketiga adalah hasil apresiasi satra reseptif terhadap teks puisi siswa kelas X MIPA 9 di SMA Negeri 1 Singaraja yang belum tergolong sempurna. Kelahiran sebuah puisi tidak akan pernah lepas dari tanggapan atau masukan pembacanya. Untuk menjadikan sebuah karya itu menjadi lebih baik, diperlukan sebuah apresiasi terhadapnya agar mendapat penghargaan dan penilaian baik atau buruknya. Apresiasi sastra reseptif ini sebatas menikmati, menghami, serta menanggapi keadaan puisi siswa.

Hal itu sejalan dengan pendapat Disick (dalam Waluyo, 2005) menyebutkan adanya empat tingkatan apresiasi, yaitu menggemari, menikmati, mereaksi, dan produktif. Pada tingkat menggemari berkaitan dengan puisi, seseorang sebatas senang membaca atau menyaksikan pembacaan puisi. Pada tingkat menikmati, seseorang akan tersentuh batinnya saat membaca puisi atau menyaksikan pembacaan puisi. Pada tingkat mereaksi, sikap kritis seseorang 
terhadap puisi lebih menonjol karena telah mampu menafsirkan dengan kritis dan memberikan penilaian baik atau buruk pada puisi. Tingkat produktif mempunyai arti bahwa seorang apresiator telah mampu menghasilkan, mengkritik, mendeklamasikan, atau membuat resensi terhadap sebuah puisi secara tertulis. Dari keempat tingakatan tersebut, apresiasi sastra reseptif hanya sampai pada tingkat ketiga.

Hasil apresiasi sastra secara reseptif terhadap teks puisi siswa ini adalah secara keseluruhan memiliki kekurangan dan kelebihannya masingmasing. Dengan ungkapan lain, puisi siswa belum memasuki kata sempurna. Dilihat dari segi struktur fisik dan struktur batin puisi siswa ini, hanya terdapat 10 buah pusi yang lengkap mengandung seluruh kriteria struktur puisi. Berdasarkan hasil resepsi puisi, ditemukan beragam makna puisi. Walaupun dalam tema yang sama, siswa dapat dikatakan bagus dalam menuangkan gagasannya dalam menulis puisi. Hasil puisi siswa juga bervariasi adanya.

Ketiga temuan di atas ada kesesuaiannya dengan hasil penelitian sejenis yang digunakan dalam penelitian ini. Yang pertama adalah penelitian yang dilakukan oleh Kamilah pada tahun 2016 dengan judul "Analisis Struktur Fisik dan Struktur Batin Puisi Siswa Kelas VIII A MTs Al-Khairiah Tegallinggah, Kecamatan Sukada". Hasil penelitian ini adalah keberhasilan siswa kelas VIII A MTs AlKhairiah Tegallinggah, Kecamatan Sukada dalam memenuhi kriteria struktur fisik dan struktur batin puisi. Hal ini memiliki kesesuaian dalam penelitian yang dilakukan. Berdasarkan hasil penelitian, keberhasilan siswa kelas $X$ MIPA 9 di SMA Negeri 1 Singaraja dalam menulis puisi yang dianalisis berdasarkan struktur dan apresiasi reseptifnya dapat dikatakan baik karena sudah mengandung kelima kriteria struktur fisik puisi (diksi yang mengandung makna kias, simbol, dan rima, pengimajian, dan kata konkret) dan keempat struktur batin (tema, nada, perasaan, dan amanat).

Penelitian sejenis yang kedua dilakukan oleh Istiningsih yang berjudul "Pelaksanaan Pembelajaran Puisi di sekolah Menengah Pertama (Studi Kasus SMP Negeri 2 Baki, Sukoharjo)" pada tahun 2010. Penelitian ini merupakan penelitian studi kasus di SMP Negeri 2 Baki. Hasil yang didapatkan dalam penelitian ini yaitu pelaksanaan pembelajaran puisi di SMP Negeri 2 Baki belum bersifat apresiatif dan masih memiliki hambatan. Namun, upaya mengatasi hambatan tersebut sudah disusun dan digunakan dalam pembelajaran. Hasil yang paling berkaitan dengan penelitian yang penulis lakukan adalah deskripsi penilaian terhadap hasil puisi siswa. Berdasarkan hasil penilaian, keadaan puisi siswa SMP Negeri 2 Baki belum masuk kategori puisi sempurna. Hal ini sesuai dengan hasil apresiasi secara reseptif yang dilakukan penulis. Dalam apresiasi resptif ini, diperoleh kekurangan dan kelebihan pada masingmasing puisi yang ditulis oleh siswa. Teks puisi siswa kelas X MIPA 9 di SMA Negeri 1 Singaraja juga dapat dikatakan belum sempurna.

\section{SIMPULAN DAN SARAN}

Berdasarkan pemaparan di atas, dapat ditarik simpulannya sebagai berikut ini. Yang pertama, teks puisi siswa kelas $X$ MIPA 9 di SMA Negeri 1 Singaraja sudah cukup baik dalam memenuhi struktur fisik dan struktur batin puisi. Teks puisi siswa kelas X MIPA 9 di SMA Negeri 1 Singaraja sudah menggunakan struktur fisik berupa diksi (makna kias, simbol, dan rima), pengimajian, dan kata konkret. Teks puisi siswa kelas X MIPA 9 di SMA Negeri 1 Singaraja juga sudah menggunakan struktur batin berupa tema, nada dan suasana, serta amanat. Yang kedua adalah apresiasi reseptif terhadap teks puisi siswa kelas X MIPA 9 di SMA Negeri 1 Singaraja yang dapat dikategorikan belum sempurna. Hasil apresiasi sastra secara reseptif terhadap teks puisi siswa ini adalah secara keseluruhan memiliki kekurangan dan kelebihannya masing-masing. Dengan ungkapan lain, puisi siswa belum tergolong sempurna. Dilihat dari segi struktur fisik dan struktur batin puisi siswa ini, hanya terdapat 10 buah pusi yang lengkap mengandung seluruh kriteria struktur puisi. 
Penelitian ini masih sebatas menganalisis struktur fisik dan struktur batin serta melakukan apresiasi secara reseptif pada teks puisi siswa kelas $X$ MIPA 9 di SMA Negeri 1 Singaraja. Ada beberapa saran yang dapat disampaikan. Siswa hendaknya mampu lebih menyempurnakan puisinya dengan melakukan upaya perbaikan berdasarkan kriteria struktur fisik dan struktur batin pada penelitian ini. Guru mata pelajaran hendaknya dapat memberikan bimbingan berupa upaya perbaikan penulisan puisi pada siswa, sehingga menghasilkan puisi yang lebih sempurna. Bagi peneliti lain, penelitian ini dapat dijadikan referensi untuk penelitian sejenis lainnya. Penelitian ini diharapkan dapat dikembangkan lagi dengan melakukan analisis resepsi respons guru mata pelajaran terhadap teks puisi siswa.

\section{DAFTAR PUSTAKA}

Aminuddin.2004.Pengantar Apresiasi Karya Sastra.Bandung: Sinar Baru Algensindo.

Gunatama, Gede.2010.Buku Ajar Puisi (Teori, Apresiasi, dan Pemaknaan). Singaraja: Universitas Pendidikan Ganesha.

Istiningsih. 2010. "Pelaksanaan Pembelajaran Puisi di sekolah Menengah Pertama (Studi Kasus SMP Negeri 2 Baki, Sukoharjo)". Skripsi (tidak diterbitkan). Jurusan Pendidikan Bahasa, Sastra Indonesia dan Daerah. Fakultas Keguruan dan Ilmu Pendidikan. Universitas Muhammadiyah Surakarta.

Kamilah, Solehatul.2016."Analisis Struktur Fisik dan Struktur Batin Puisi Siswa Kelas VIII A MTs Al-Khairiah Tegallinggah, Kecamatan Sukada". Skripsi (tidak diterbitkan). Jurusan Pendidikan Bahasa dan Sastra Indonesia. Fakultas Bahasa dan Seni. Universitas Pendidikan Ganesha.

Pradopo, Rachmat Djoko.1993.Beberapa Teori Sastra, Metode, dan Penerapannya. Yogyakarta: Pustaka Pelajar.
Ratna, Nyoman Kutha.2003.Paradigma Sosiologi Sastra. Yogyakarta: Pustaka Pelajar.

Sudiara, I Nyoman Seloka.Dalam forum kuliah Kritik Sastra pada 26 Agustus 2014 di Universitas Pendidikan Ganesha.

Sugihastuti.2002.Teori dan Apresiasi Sastra.Yogyakarta: Pustaka Pelajar.

Waluyo, Herman J.1995.Teori dan Apresiasi Puisi. Surakarta: Erlangga.

2005.Apresiasi Puisi Panduan Untuk Pelajar dan Mahasiswa. Jakarta: Gramedia Pustaka Utama.

Yasa, I Nyoman.2012.Teori Sastra dan Penerapannya. Bandung: CV Karya Putra Darwati.

Zaidan, Abdul Rozak.1991.Kamus Istilah Sastra.Jakarta: Pusat Pembinaan dan Pengembangan Bahasa. 